\title{
SISTEM REKOMENDASI PENERIMAAN MAHASISWA BARU MENGGUNAKAN NAIVE BAYES CLASSIFIER DI INSTITUT PENDIDIKAN INDONESIA
}

\author{
Andri Suryadi ${ }^{1}$, Erwin Harahap ${ }^{2}$ \\ ${ }^{1}$ Program Studi Pendidikan Teknologi Informasi, Institut Pendidikan Indonesia Garut. \\ ${ }^{2}$ Program Studi Matematika, FMIPA, Universitas Islam Bandung. \\ suryadi.andri@yahoo.com, erwin2h@unisba.ac.id
}

\begin{abstract}
The quality of a university in creating qualified graduates is determined by the prospective students who enter the college. One of the things that can determine the quality is how the selection process of candidates for good student acceptance. However, the selection process of admissions in every college of course is different. Often the input of prospective students who enter the university is not in accordance with the expected so that the impact of graduate results. Therefore it is necessary for a system that can support the decision in the selection of new student candidates in order to get a good student input. This research builds a Recommendation System that will assist in the selection process of universities for the selection team of new student candidates. This recommendation system uses the naïve Bayes classifier method where the test scores of incoming selection of students who have been accepted will be used as training data and then classified based on the value of ipk that has been obtained. The value of the ipk will be a benchmark for the formation of classes - classes that are recommendations to the selection team. The classes that are formed are classes whose ipk value is at the accepted point and the class whose ipk value is not accepted. Then given a new student data, if the prospective student enters the safe class then it will be recommended to be accepted but otherwise it will be recommended to be rejected
\end{abstract}

Keyword : Recommendation System, Naïve bayes Classifier, College.

\section{PENDAHULUAN}

\subsection{Latar belakang}

Setiap Pendirian Perguruan Tinggi memiliki tujuan menghasilkan lulusan yang berkualitas dan berdaya saing. Namun dalam menghasilkan lulusan yang berkualitas tentunya tidak terlepas dari input calon mahasiswa dalam proses seleksi masuk perguruan tinggi. Hal ini sejalan dengan pendapat M.Rosul Asmawi (2006) yang mengatakan bahwa untuk dapat menghasilkan produk yang baik maka harus menanam bibit - bibit yang baik. Untuk mendapatkan bibit yang baik perlu adanya seleksi yang baik pula. Dengan demikian untuk mendapatkan calon mahasiswa yang berkualitas maka perlu adanya saringan yang baik.

Masing - masing Perguruan Tinggi tentunya memiliki sistem sendiri dalam proses seleksi masuk (Giovani, Ronny Ardi.2011). Hanya saja biasanya dalam pelaksanaan proses seleksi yang dilakukan banyak mahasiswa yang nilai kelulusannya tidak sesuai yang diharapkan. Oleh karena itu perlu adanya suatu sistem yang dapat mendukung keputusan dalam seleksi calon mahasiswa baru guna mendapatkan input calon mahasiswa yang baik sebagai prediksi guna memperoleh hasil seleksi yang baik (A. G. Mabrur and R. Lubis.2012).
Penelitian ini bertujuan untuk membangun sebuah Sistem Rekomendasi yang akan membantu dalam tim dalam proses seleksi perguruan tinggi calon mahasiswa baru. Sistem Rekomendasi ini menggunakan metode naive bayes classifier dimana nilai tes kompetensi dasar mahasiswa yang telah diterima akan dijadikan data latih kemudian diklasifikasikan berdasarkan nilai ipk yang telah diperolehnya (Septian Nugroho, Y.2014). Nilai ipk tersebut akan menjadi patokan pembentukan kelas kelas yang merupakan rekomendasi kepada tim penyeleksi. Kelas - kelas rekomendasi yang terbentuk adalah kelas yang nilai ipk nya berada pada titik diterima dan kelas yang nilai ipk nya tidak berada pada titik tidak diterima. Kemudian diberikan sebuah data calon mahasiswa beserta hasil nilai seleksinya, jika calon mahasiswa tersebut memasuki kelas diterima maka akan direkomendasikan untuk memasuki Perguruan Tinggi yang dimaksud. Namun sebaliknya jika calon mahasiswa tersebut berada pada kelas tidak diterima maka calon mahasiswa tersebut tidak direkomendasikan untuk memasuki Perguruan Tinggi.

Dengan adanya sistem ini diharapkan input dari calon mahasiswa akan lebih baik dan akan berdampak pada kualitas lulusan dari Perguruan Tinggi. 


\subsection{Permasalahan penelitian}

Mengacu pada latar belakang yang telah diuraikan sebelumnya, maka rumusan masalah pada penelitian ini adalah sebagai berikut:

a. Bagaimana membangun Sistem Rekomendasi menggunakan metode naïve bayes dalam proses seleksi penerimaan calon mahasiswa baru?

b. Bagaimana Sistem Rekomendasi menggunakan metode naïve bayes ini dapat membantu dalam proses seleksi penerimaan mahasiswa baru?

\subsection{Wawasan dan rencana pemecahan masalah}

Sistem Rekomendasi yang akan dibangun ini menggunakan metode naive bayes classifier sedangkan pembangunan aplikasinya sistem rekomendasi ini menggunakan model waterfall.

\subsection{Tujuan Penelitian}

Tujuan yang ingin dicapai dari penelitian ini adalah sebagai berikut:

a. Sebagai Sistem Pendukung Keputusan yang dapat membantu merekomendasikan tim penyeleksi dalam memilih calon mahasiswa sesuai yang diinginkan.

b. Membantu proses seleksi penerimaan mahasiswa baru.

c. Dapat meningkatkan input kualitas dari calon mahasiswa.

\section{PEMBAHASAN}

Sistem Pendukung Keputusan merupakan sistem informasi interaktif yang menyediakan informasi, pemodelan, dan pemanipulasian data. Sistem ini digunakan untuk membantu pengambilan keputusan dalam situasi yang semiterstruktur dan situasi yang tidak terstruktur, dimana tak seorang pun tahu secara pasti bagaimana keputusan seharusnya dibuat (Turban, 2005). Pengambilan keputusan secara universal didefinisikan sebagai pemilihan diantara berbagai alternatif. Pengertian ini mencakup baik pembuatan pilihan pemecahan masalah.

Pengambilan keputusan pada hakekatnya terdapat tiga langkah utama (Simon, 1977) yaitu:
a. Kegiatan Intelijen
Menyangkut pencarian berbagai kondisi lingkungan yang diperlukan bagi keputusan.
b. Kegiatan Desain
Tahap ini menyangkut pembuatan pengembangan dan penganalisaan berbagai rangkaian kegiatan yang mungkin dilakukan.
c. Kegiatan Pemilihan
Pemilihan serangkaian kegiatan tertentu dari alternatif yang tersedia.

Dalam pengambilan keputusan terdapat karakteristik dan kemampuan ideal (Turban,2005) seperti digambarkan pada gambar 2.1 dibawah ini

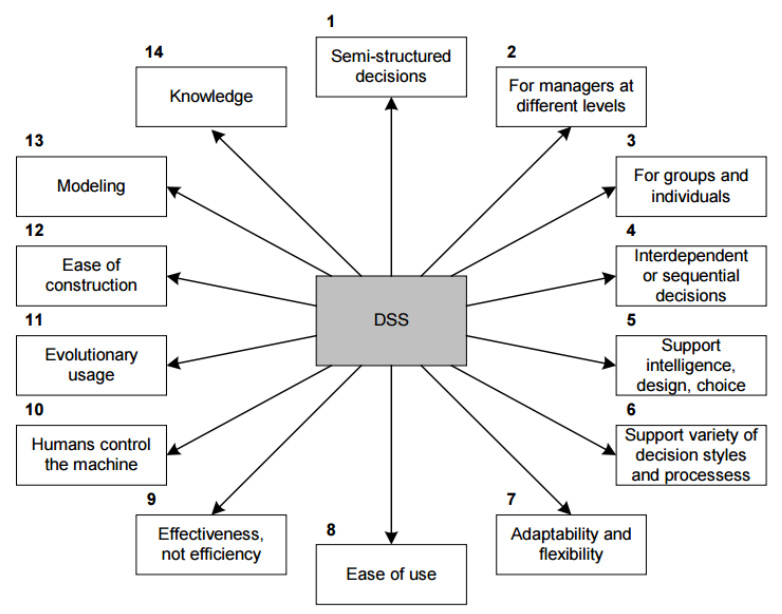

Gambar 2.1 Karakteristik dan kemampuan ideal pendukung keputusan

1) Pendukung keputusan menyediakan dukungan bagi pengambil keputusan utamanya dalam situasi semi terstruktur dan tak terstruktur dengan memadukan pertimbangan manusia dan informasi terkomputerasi. Berbagai masalah tak dapat diselesaikan (atau tak dapat diselesaikan secara memuaskan) oleh sistem terkomputerisasi lain, seperti EDP atau MIS, tidak juga dengan metode atau tool kuantitatif standar.

2) Dukungan disediakan untuk berbagai level manajerial yang berbeda, mulai dari pimpinan puncak sampai manajer lapangan.

3) Dukungan disediakan bagi individu dan juga bagi group. Berbagai masalah organisasi melibatkan pengambilan keputusan dari dalam group. Untuk masalah yang strukturnya lebih sedikit sering kali hanya membutuhkan keterlibatan beberapa individu dari departemen dan level organisasi yang berbeda.

4) Sistem pendukung keputusan menyediakan dukungan ke berbagai keputusan yang berurutan atau saling berkaitan.

5) Sistem pendukung keputusan mendukung berbagai fase proses pengambilan keputusan: kegiatan intelejen, desain dan pemilihan.

6) Sistem pendukung keputusan mendukung berbagai proses pengambilan keputusan dan style yang berbeda-beda.

7) Sistem pendukung keputusan selalu bisa beradaptasi sepanjang masa. Pengambilan keputusan harus reaktif, mampu mengatasi perubahan kondisi secepatnya dan beradaptasi untuk dapat menangani perubahan. 
8) Sistem pengambilan keputusan mudah untuk digunakan. Pengguna harus merasa nyaman dengan sistem ini.

9) Sistem pengambilan keputusan mencoba untuk meningkatkan efektivitas dari pengambilan keputusan (akurasi, jangka, waktu, kualitas).

10) Pengambilan keputusan memiliki control yang menyeluruh terhadap semua langkah proses pengambilan keputusan dalam menyelesaikan masalah. Sistem pengambilan keputusan secara khusu ditujukan untuk mendukung dan tak menggantikan pengambil keputusan. Pengambilan keputusan dapat menindaklanjuti rekomendasi komputer sembarang waktu dalam proses dengan tambahan pendapat pribadi atau pun tidak.

11) Sistem pengambilan keputusan mengarah pada pembelajaran, yaitu mengarah pada kebutuhan baru dan penyempurnaan sistem, yang mengarah pada pembelajaran tambahan dan begitu selanjutnya dalam proses pengembangan dan peningkatan keputusan secara berkelanjutan.

12) Pengguna harus mampu menyusun sendiri sistem yang sederhana. Sistem yang lebih besar dapat dibangun dalam organisasi pengguna tadi dengan melibatkan sedikit saja bantuan dari spesialis dibidang sistem informasi.

13) Sistem pengambilan keputusan biasanya mendayagunakan berbagai model (standar atau sesuai keinginan pengguna) dalam menganalisis berbagai keputusan.

14) Sistem pengabilan keputusan dalam tingkat lanjut dilengkapi dengan komponen pengetahuan yang bisa memberikan silusi yang efisien dan efektif dari berbagai masalah yang pelik.

Masih menurut (Turban, 2005) dalam pemakaian sistem pendukung keputusan terdapat beberapa keuntungan diantaranya:

1) Mampu mendukung pencarian solusi dari masalah yang kompleks

2) Respon cepat pada situasi yang tak diharapkan dalam kondisi yang berubah-ubah.

3) Mampu menerapkan berbagai strategi yang berbeda pada konfigurasi berbeda secara cepat dan tepat.

4) Pandangan dan pembelajaran baru.

5) Memfasilitasi komunikasi.

6) Meningkatkan control manajemen dan kinerja.

7) Menghemat biaya.

8) Keputusan lebih tepat.
9) meningkatkan efektifitas menajerial, menjadikan seseorang dapat bekerja lebih singkat dan dengan sedikit usaha.

10) Meningkatkan produktivitas analisis.

\section{Sistem Pendukung Keputusan Model Waterfall}

Dalam pengembangan Sistem Pendukung Keputusan ini menggunakan model waterfall. Model waterfall adalah proses pengembangan perangkat lunak tradisional yang umum digunakan dalam proyek-proyek perangkat lunak yang paling pembangunan. Ini adalah model sekuensial, sehingga penyelesaian satu set kegiatan menyebabkan dimulainya aktivitas berikutnya. Berikut gambar model waterfall:

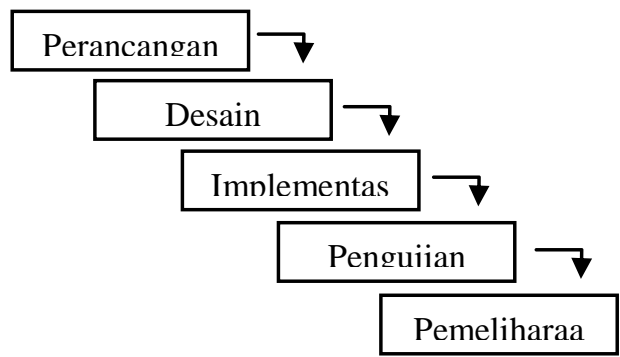

Gambar 2.2 Waterfall

1) Perancangan / Analisis Sistem

Ini adalah langkah pertama dan paling penting dari model waterfall. Ini melibatkan pengumpulan informasi mengenai solusi akhir dari kebutuhan pelanggan pelanggan dan pemahaman. Ini melibatkan definisi yang jelas tentang tujuan pelanggan, harapan terhadap proyek dan masalah produk akhir diharapkan untuk memecahkan.

2) Desain Sistem

Langkah ini dimulai dengan menggunakan informasi yang ditangkap di SRS. Ini dapat dianggap sebagai memberikan solusi untuk masalah di lingkup menggunakan sumber daya yang tersedia. Tahap ini terdiri dari bagaimana perangkat lunak akan dibangun, dengan kata lain perencanaan solusi perangkat lunak. Para pemangku kepentingan yang terlibat dalam modul ini adalah para perancang sistem. Desain perangkat lunak mungkin mencakup desain sistem dan desain komponen

3) Implementasi

Masukan dari fase ini adalah SDD sistem. "Di sinilah perkembangan aktual sistem terjadi sesuai dengan spesifikasi desain. Langkah ini dilakukan oleh pengembang, desainer interface dan stakeholder lainnya dengan menggunakan alat seperti compiler, debugger, penerjemah dan 
editor media. Output dari langkah ini adalah komponen produk satu atau lebih yang dibangun berdasarkan standar yang telah ditetapkan coding dan perbaikan, pengujian dan terintegrasi untuk memenuhi kebutuhan arsitektur sistem

4) Pengujian

Pada fase ini kedua komponen individu dan solusi terintegrasi yang diverifikasi untuk melihat itu adalah bug gratis dan memenuhi spesifikasi kebutuhan perangkat lunak. Tester adalah stakeholder yang terlibat dalam fase model. Cacat yang ditemukan pada tahap ini diberikan sebagai umpan balik kepada para pengembang yang pada gilirannya memperbaiki masalah. Ini adalah tahap di mana produk dikembangkan didokumentasikan.

5) Pemeliharaan

Ini adalah tahap akhir dari model waterfall dan terjadi setelah instalasi sistem produk / di lokasi pelanggan. "Tahap ini melibatkan membuat modifikasi pada sistem atau komponen individu untuk mengubah atribut atau meningkatkan kinerja sistem". Modifikasi yang muncul karena perubahan permintaan dipicu oleh pelanggan atau cacat yang ditemukan saat menggunakan sistem secara real time. Nomor revisi diperbarui dalam setiap rilis pemeliharaan.

\section{Naïve Bayes Classifier}

Nä̈ve Bayes Classifier merupakan teknik prediksi pengklasifikasian berbasis probabilistic sederhana berdasar pada penerapan teorema Bayes (aturan Bayes) dengan asumsi independensi (ketidaktergantungan) yang kuat (naif). Maksud independensi yang kuat adalah bahwa sebuah data tidak berkaitan dengan ada atau tidaknya data yang sama. Prediksi Bayes didasarkan pada teorema Bayes dengan formula umum sebagai berikut:

$$
P(H \mid E)=\frac{P(H \mid E) \times P(H)}{P(E)}
$$

\section{Gambar 2.3 Rumus Naïve Bayes}

Penjelasan dari formula tersebut adalah sebagai berikut:

$\begin{array}{ll}\text { Parameter } & : \text { Keterangan } \\ \mathrm{P}(\mathrm{H} \mid \mathrm{E}) & : \text { Probabilitas akhir bersyarat } \\ & \text { (conditional probility) suatu } \\ & \text { hipotesis } \mathrm{H} \text { terjadi jika diberikan } \\ & \text { bukti (evidence) E terjadi. } \\ \mathrm{P}(\mathrm{E} \mid \mathrm{H}) & : \text { Probabilitas sebuah bukti E terjadi } \\ & \text { akan mempengaruhi hipotesis } \mathrm{H} .\end{array}$

$\mathrm{P}(\mathrm{H})$

$$
\begin{aligned}
& \text { : Probabilitas awal (prior) hipotesis } \\
& \text { H terjadi tanpa memandang bukti } \\
& \text { apapun. } \\
& \text { : Probabilitas awal (prior) bukti E } \\
& \text { terjadi tanpa memandang hipotesis } \\
& \text { bukti yang lain. }
\end{aligned}
$$

Dari penjelasan diatas dapat disimpulkan bahwa hasil dari hipotesis atau peristiwa $(\mathrm{H})$ diperkirakan berdasarkan pada beberapa bukti (E) yang diamati. ada beberapa hal penting dari aturan tersebut, yaitu:

1) Sebuah probabilitas awal / prior $\mathrm{H}$ atau $\mathrm{P}(\mathrm{H})$ adalah probabilitas dari suatu hipotesis sebelum bukti diamati.

2) Sebuah probabilitas akhir $\mathrm{H}$ atau $\mathrm{P}(\mathrm{H} \mid \mathrm{E})$ adalah probabilitas dari suatu hipotesis setelah bukti diamati.

Jadi dapat disimpulkan bahwa jika $\mathrm{H}$ merupakan vektor masukan yang berisi fitur dan $\mathrm{E}$ adalah label kelas, maka dalam naïve bayes dituliskan $\mathrm{P}(\mathrm{H} \mid \mathrm{E})$. Notasi tersebut berarti probabilitas label kelas E didapatkan setelah fitur-fitur $\mathrm{H}$ diamati. Notasi ini disebut juga probabilitas akhir (posterior probability) untuk E, sedangkan $\mathrm{P}(\mathrm{E})$ disebut probabilitas awal (prior probability)

\section{Klasifikasi dalam Proses Seleksi Ujian Masuk Perguruan Tinggi}

Proses Seleksi Ujian Masuk Perguruan Tinggi merupakan proses penting sebelum mahasiswa menempuh pendidikan disebuah Perguruan Tinggi. Biasanya setiap Perguruan Tinggi mempunyai visi dan misi yang berbeda-beda. Untuk mencapai hal tersebut dibutuhkan karakteristik input mahasiwa yang sesuai dengan apa yang diinginkan oleh Perguruan Tinggi.

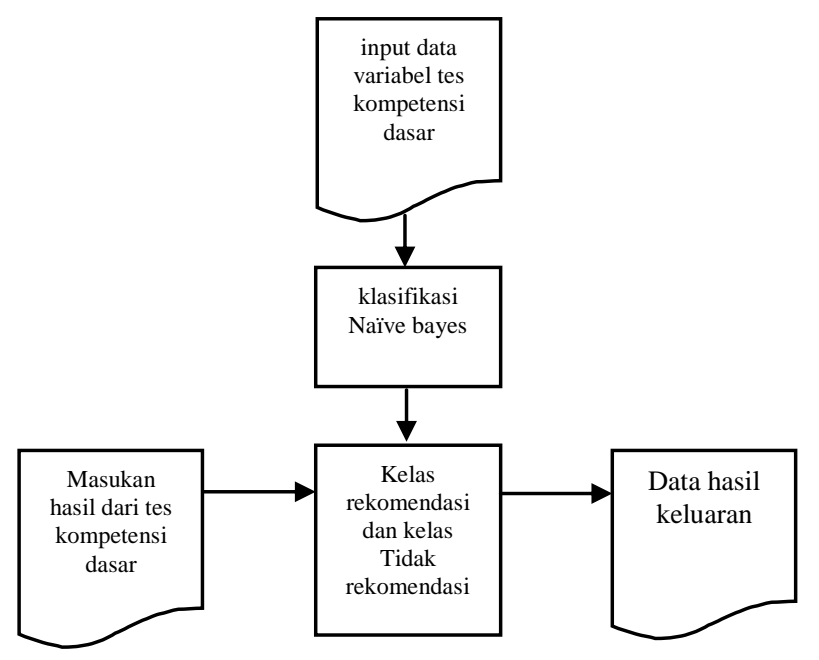

Gambar 2.4 Gambar alur klasifikasi proses seleksi 
Input data variabel tes merupakan data masukan yang akan dijadikan data latih menggunakan naïve bayes. Data latih tersebut akan diklasifikasikan sehingga menghasilkan kelas yang direkomendasikan dan tidak direkomendasikan. Setelah terciptanya kelas kemudian akan diuji data baru yang merupakan data nilai kompetensi dasar calon mahasiswa. Hasil akhir dari pengolahan data calon mahasiswa baru ini adalah kelas yang ditempatinya apakah masuk kedalam kelas rekomendasi atau tidak.

\section{METODE PENELITIAN}

\section{Tahapan Penelitian}

Tahapan penelitian dalam Sistem Pendukung Keputusan Seleksi Ujian Masuk Perguruan Tinggi ini dapat dilihat pada gambar 1 dengan penjelasan sebagai berikut:

1. Studi Literatur

2. Tahap pertama dalam penelitian ini adalah studi literature. Dalam studi literatur ini terdapat dua tahapan yaitu tentang sistem pendukung keputusan, model waterfall naive bayes dan naive bayes dalam seleksi ujian masuk Perguruan Tinggi.

3. Data Penelitian

4. Data penelitian terdapat dua macam yaitu data latih dan data uji. Data latih merupakan nilai dari tes kompetensi dasar mahasiswa pada waktu awal masuk ke Program Studi Pendidikan Teknologi Informasi. Sedangkan data uji adalah data calon mahasiswa yang akan masuk ke Program Studi Teknologi Informasi.

5. Perangkat Lunak Model Waterfall

6. Pembangunan Sistem Pendukung Keputusan menggunakan model waterfall. Model ini memiliki tahapannya diantaranya perancangan atau analisis sistem, desain sistem, implementasi, pengujian dan pemelliharaan. Dari pembangunan perangkat lunak ini menghasilkan kelas dari data latih kemudian akan diuji coba dengan data uji dari calon mahasiswa.

7. Klasifikasi Calon Mahasiswa

8. Klasifikasi merupakan nilai akhir rekomendasi dari sistem pendukung keputusan ini. Nilai akhir ini akan memunculkan apakah calon mahasiswa tersebut diterima atau ditolak.

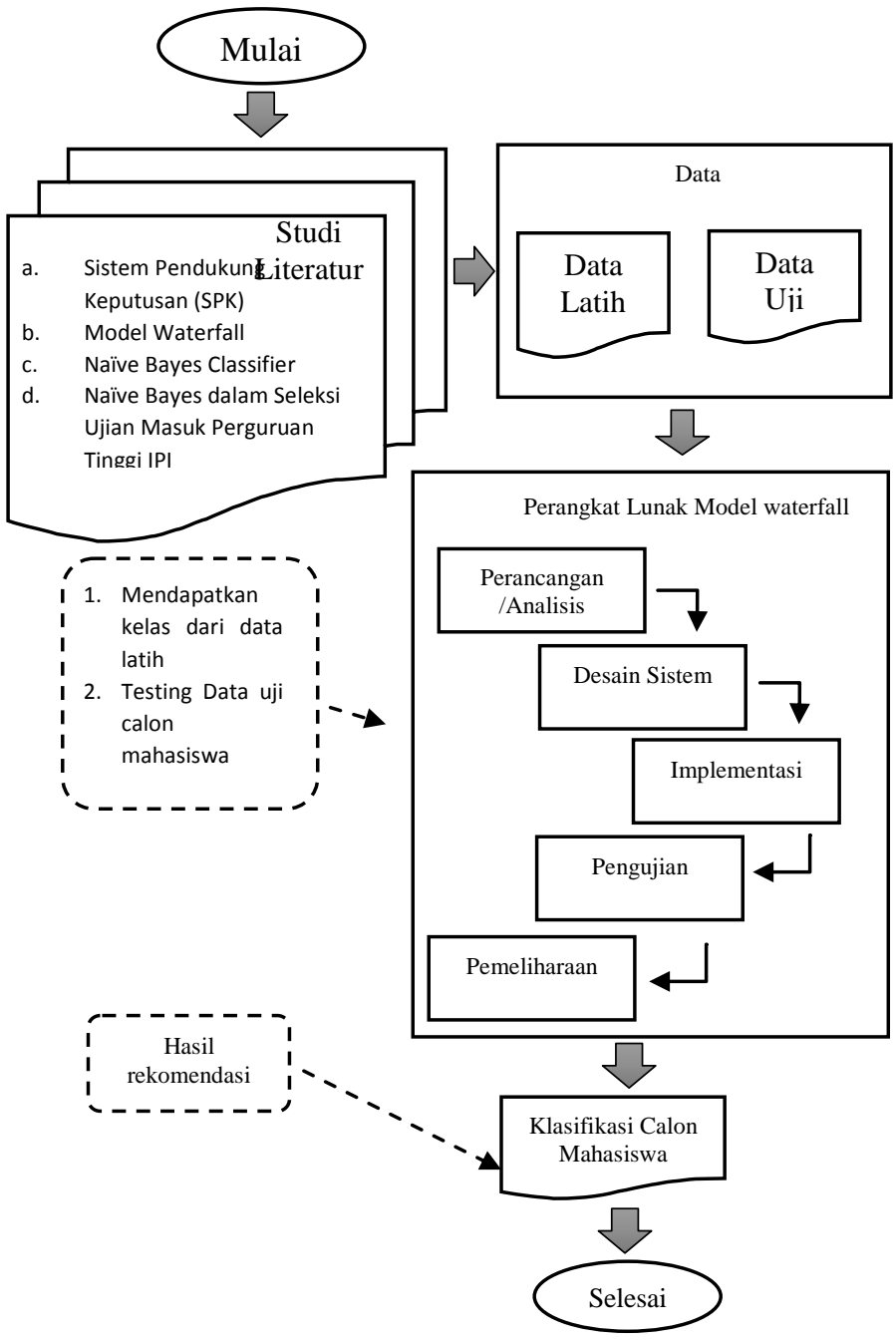

Gambar 1. Tahapan Penelitian

\section{Teknik Pengumpulan Data}

Teknik yang digunakan dalam penelitian ini adalah teknik wawancara dan observasi. Teknik wawancara dilakukan terhadap sample Program Studi di Institut Pendidikan Indonesia. Teknik wawancara ini akan menghasilkan kualitas calon mahasiswa yang diinginkan dan akan memasuki program studi tersebut sehingga menjadi acuan batas ambang dalam penentuan kelas. Sedangkan teknik observasi merupakan teknik analisis data dari nilai-nilai tes kompetensi dasar mahasiswa yang telah dilakukan. Data nilai tes kompetensi dasar ini akan dijadikan data latih pada sistem pendukung keputusan yang akan dibuat. Dengan dilakukannya teknik wawancara dan observasi diharapkan data yang akan dijadikan data latih menjadi lebih reliable. 


\section{Lokasi Penelitian}

Penelitian ini akan dilaksanakan di Institut Pendidikan Indonesia dengan sampel data latih adalah data mahasiswa aktif. Sedangkan data input adalah data calon mahasiswa yang akan memasuki Institut Pendidikan Indonesia.

\section{HASIL PEMBAHASAN}

\section{Data Penelitian}

Untuk membuat Sistem Pendukung Keputusan Seleksi Ujian Masuk Perguruan Tinggi Menggunakan NBC (Naïve Bayes Classifier) ini hal yang paling penting adalah data penelitian yang terdiri dari data latih dan data uji. Data latih merupakan data mahasiswa yang telah menjalankan proses perkuliahan di Institut Pendidikan Indonesia yang disimpan dalam database yang akan diolah. Sedangkan data uji dalam penelitian ini adalah data calon mahasiswa baru yang akan diujikan terhadap sistem pendukung keputusan ini

\section{Data Latih}

Sebagaimana telah dijelaskan sebelumnya data latih merupakan data mahasiswa yang telah menjalani proses perkuliahan. Dalam hal ini mahasiswa Program Studi Pendidikan Teknologi Informasi. Variabel pada data latih yang diambil berupa nilai pada masing-masing mahasiswa pada saat tes seleksi masuk calon mahasiswa baru dan nilai ipk yang diperoleh sekarang. Nilai tes seleksi masuk adalah nilai matematika, bahasa indonesia, bahasa inggris, kewarganegaraan serta hasil wawancara berupa jarak dari tempat tinggal, status bekerja, keaktifan organisasi sedangkan ipk merupakan hasil dari studi saat ini. Berikut adalah data mahasiswa yang akan dijadikan data latih pada sistem pendukung keputusan ini:

Tabel 4.1 Data Latih

\begin{tabular}{|c|c|c|c|c|c|c|c|c|}
\hline \multirow{2}{*}{$\begin{array}{l}\text { Nama } \\
\text { Calon } \\
\text { Mahasis } \\
\text { wa }\end{array}$} & \multicolumn{4}{|c|}{ Nilai Seleksi } & \multirow{2}{*}{ B } & \multirow{2}{*}{$\mathrm{O}$} & \multirow{2}{*}{$\mathrm{J}$} & \multirow{2}{*}{ ipksms 1-6 } \\
\hline & $\mathbf{V}$ & $\mathbf{K}$ & $\mathbf{P}$ & $\mathbf{W}$ & & & & \\
\hline $\begin{array}{l}\text { DADAN } \\
\text { G } \\
\text { MUHAI } \\
\text { MIN }\end{array}$ & $\mathrm{S}$ & B & K & S & $\mathrm{Y}$ & $\mathrm{T}$ & JAUH & KURANG \\
\hline $\begin{array}{l}\text { FAJAR } \\
\text { RENDI } \\
\text { M }\end{array}$ & $S$ & $\mathrm{C}$ & S & S & Y & Y & JAUH & KURANG \\
\hline $\begin{array}{l}\text { EDWIN } \\
\text { DWITA } \\
\text { MA S }\end{array}$ & $\mathrm{S}$ & $\mathrm{C}$ & S & $S$ & Y & $\mathrm{T}$ & DEKAT & $\begin{array}{l}\text { REKOMENDA } \\
\text { SI }\end{array}$ \\
\hline $\begin{array}{l}\text { NOVA } \\
\text { MENTA } \\
\text { RI }\end{array}$ & $\mathrm{S}$ & S & K & S & $\mathrm{T}$ & $\mathrm{T}$ & DEKAT & $\begin{array}{c}\text { REKOMENDA } \\
\text { SI }\end{array}$ \\
\hline $\begin{array}{l}\text { AYU } \\
\text { LESTAR } \\
\text { I }\end{array}$ & $\mathrm{S}$ & $\mathrm{C}$ & K & $\mathrm{K}$ & $\mathrm{Y}$ & $\mathrm{Y}$ & DEKAT & $\begin{array}{l}\text { REKOMENDA } \\
\text { SI }\end{array}$ \\
\hline $\begin{array}{l}\text { SAEPUL } \\
\text { HIDAYA } \\
\mathrm{T} \\
\end{array}$ & $\mathrm{K}$ & $\mathrm{K}$ & $\mathrm{C}$ & 7 & $\mathrm{~T}$ & $\mathrm{~T}$ & JAUH & KURANG \\
\hline
\end{tabular}

\begin{tabular}{|c|c|c|c|c|c|c|c|c|}
\hline \multirow{2}{*}{$\begin{array}{l}\text { Nama } \\
\text { Calon } \\
\text { CITRA } \\
\text { RETNO } \\
\end{array}$} & \multicolumn{4}{|c|}{ Nilai Seleksi } & \multirow{2}{*}{$\begin{array}{l}\mathrm{B} \\
\mathrm{T} \\
\end{array}$} & \multirow{2}{*}{$\begin{array}{l}\mathrm{O} \\
\mathrm{T} \\
\end{array}$} & \multirow{2}{*}{$\begin{array}{c}\mathrm{J} \\
\text { DEKAT }\end{array}$} & \multirow{2}{*}{$\begin{array}{c}\text { ipksms } 1-6 \\
\text { REKOMENDA } \\
\text { SI } \\
\end{array}$} \\
\hline & $\mathrm{S}$ & $\mathrm{S}$ & $\mathrm{K}$ & $\mathrm{K}$ & & & & \\
\hline $\begin{array}{l}\text { IQBAL } \\
\text { AHMAD } \\
\text { MAULA } \\
\text { NA }\end{array}$ & $\mathrm{S}$ & $\mathrm{C}$ & S & K & $\mathrm{Y}$ & $\mathrm{Y}$ & DEKAT & $\begin{array}{c}\text { REKOMENDA } \\
\text { SI }\end{array}$ \\
\hline $\begin{array}{l}\text { AHMAD } \\
\text { FAUZI } \\
\text { HIKAMI }\end{array}$ & $\mathrm{S}$ & $\mathrm{C}$ & $\mathrm{K}$ & $\mathrm{K}$ & $\mathrm{T}$ & $\mathrm{T}$ & JAUH & KURANG \\
\hline $\begin{array}{l}\text { SANTI } \\
\text { JULIAW } \\
\text { ATI } \\
\end{array}$ & $\mathrm{S}$ & $\mathrm{S}$ & $\mathrm{K}$ & $\mathrm{K}$ & $\mathrm{Y}$ & $\mathrm{Y}$ & JAUH & $\begin{array}{l}\text { REKOMENDA } \\
\text { SI } \\
\end{array}$ \\
\hline $\begin{array}{l}\text { YUDI } \\
\text { RIYADI }\end{array}$ & $\mathrm{S}$ & $\mathrm{S}$ & K & $\mathrm{K}$ & $\mathrm{T}$ & $\mathrm{T}$ & DEKAT & KURANG \\
\hline $\begin{array}{l}\text { RAHMA } \\
\text { ALAWI } \\
\text { YAH }\end{array}$ & $\mathrm{S}$ & $\mathrm{S}$ & K & K & $\mathrm{T}$ & $\mathrm{T}$ & JAUH & KURANG \\
\hline $\begin{array}{l}\text { NOPA } \\
\text { MUSTO } \\
\text { PA }\end{array}$ & $\mathrm{K}$ & $\mathrm{K}$ & $\mathrm{S}$ & $\mathrm{K}$ & $\mathrm{T}$ & $\mathrm{T}$ & DEKAT & KURANG \\
\hline $\begin{array}{l}\text { RIZKI } \\
\text { NUR } \\
\text { IKLAS }\end{array}$ & $\mathrm{S}$ & $\mathrm{S}$ & K & $\mathrm{S}$ & $\mathrm{T}$ & $\mathrm{T}$ & JAUH & KURANG \\
\hline $\begin{array}{l}\text { ELSA } \\
\text { ERLIAN } \\
\text { TY } \\
\end{array}$ & $\mathrm{S}$ & $\mathrm{S}$ & $\mathrm{K}$ & $\mathrm{K}$ & $\mathrm{Y}$ & $\mathrm{T}$ & DEKAT & $\begin{array}{c}\text { REKOMENDA } \\
\text { SI }\end{array}$ \\
\hline $\begin{array}{l}\text { ALVY } \\
\text { RIFQIH } \\
\text { ANI }\end{array}$ & $\mathrm{K}$ & K & $\mathrm{S}$ & $\mathrm{S}$ & $\mathrm{T}$ & $\mathrm{T}$ & DEKAT & $\begin{array}{c}\text { REKOMENDA } \\
\text { SI }\end{array}$ \\
\hline $\begin{array}{l}\text { FAJAR } \\
\text { KURNIA }\end{array}$ & $\mathrm{K}$ & $\mathrm{S}$ & K & K & $\mathrm{Y}$ & $\mathrm{Y}$ & JAUH & KURANG \\
\hline $\begin{array}{l}\text { HUSNI } \\
\text { YASIR } \\
\end{array}$ & $\mathrm{K}$ & $\mathrm{C}$ & K & $\mathrm{K}$ & $\mathrm{Y}$ & $\mathrm{T}$ & JAUH & KURANG \\
\hline $\begin{array}{l}\text { IMAM } \\
\text { IHSANU } \\
\text { DIN }\end{array}$ & $\mathrm{K}$ & $\mathrm{K}$ & $\mathrm{S}$ & $\mathrm{K}$ & $\mathrm{Y}$ & $\mathrm{T}$ & JAUH & $\begin{array}{c}\text { REKOMENDA } \\
\text { SI }\end{array}$ \\
\hline $\begin{array}{l}\text { TOTOH } \\
\text { ABDUL } \\
\text { FATAH } \\
\end{array}$ & $\mathrm{S}$ & $\mathrm{S}$ & K & $\mathrm{K}$ & $\mathrm{T}$ & $\mathrm{T}$ & JAUH & $\begin{array}{c}\text { REKOMENDA } \\
\text { SI }\end{array}$ \\
\hline $\begin{array}{l}\text { RENDI } \\
\text { FIRMAN } \\
\text { SYAH } \\
\end{array}$ & $\mathrm{K}$ & $\mathrm{K}$ & S & $\mathrm{K}$ & $\mathrm{Y}$ & $\mathrm{Y}$ & JAUH & KURANG \\
\hline $\begin{array}{l}\text { ASEP } \\
\text { KUSWA } \\
\text { NDI } \\
\end{array}$ & $\mathrm{K}$ & $\mathrm{K}$ & K & $\mathrm{K}$ & $\mathrm{T}$ & $\mathrm{T}$ & JAUH & KURANG \\
\hline $\begin{array}{l}\text { SANTI } \\
\text { SUSANT } \\
\text { I }\end{array}$ & $\mathrm{K}$ & $\mathrm{K}$ & K & S & $\mathrm{Y}$ & $\mathrm{T}$ & $\begin{array}{c}\text { SEDAN } \\
\mathrm{G}\end{array}$ & KURANG \\
\hline $\begin{array}{l}\text { YULY } \\
\text { YULIAN } \\
\text { TI }\end{array}$ & $\mathrm{K}$ & $\mathrm{K}$ & K & S & $\mathrm{Y}$ & $\mathrm{Y}$ & JAUH & $\begin{array}{c}\text { REKOMENDA } \\
\text { SI }\end{array}$ \\
\hline $\begin{array}{l}\text { HANI } \\
\text { HADIYA } \\
\text { NI }\end{array}$ & $\mathrm{K}$ & $\mathrm{K}$ & S & $\mathrm{K}$ & $\mathrm{T}$ & $\mathrm{T}$ & JAUH & $\begin{array}{c}\text { REKOMENDA } \\
\text { SI }\end{array}$ \\
\hline $\begin{array}{l}\text { VICKY } \\
\text { RIDWA } \\
\text { NSYAH } \\
\end{array}$ & $\mathrm{K}$ & $\mathrm{K}$ & $\mathrm{K}$ & $\mathrm{K}$ & $\mathrm{T}$ & $\mathrm{Y}$ & JAUH & $\begin{array}{c}\text { REKOMENDA } \\
\text { SI }\end{array}$ \\
\hline $\begin{array}{l}\text { RINRIN } \\
\text { RINDI } \\
\text { REGINA }\end{array}$ & $\mathrm{K}$ & $\mathrm{K}$ & $\mathrm{K}$ & $\mathrm{S}$ & $\mathrm{Y}$ & $\mathrm{Y}$ & DEKAT & $\begin{array}{c}\text { REKOMENDA } \\
\text { SI }\end{array}$ \\
\hline $\begin{array}{l}\text { INDRI } \\
\text { HANDA } \\
\text { YANI }\end{array}$ & $\mathrm{K}$ & $\mathrm{K}$ & $\mathrm{K}$ & $\mathrm{K}$ & $\mathrm{Y}$ & $\mathrm{Y}$ & DEKAT & $\begin{array}{c}\text { REKOMENDA } \\
\text { SI }\end{array}$ \\
\hline $\begin{array}{l}\text { FAHMI } \\
\text { NUR } \\
\text { RAHMA } \\
\mathrm{N} \\
\end{array}$ & $\mathrm{K}$ & $\mathrm{K}$ & S & $\mathrm{K}$ & $\mathrm{T}$ & $\mathrm{T}$ & JAUH & $\begin{array}{c}\text { REKOMENDA } \\
\text { SI }\end{array}$ \\
\hline $\begin{array}{l}\text { TRIA } \\
\text { AMINA } \\
\text { TI } \\
\end{array}$ & $\mathrm{K}$ & $\mathrm{K}$ & $\mathrm{K}$ & $\mathrm{K}$ & $\mathrm{T}$ & $\mathrm{T}$ & JAUH & $\begin{array}{c}\text { REKOMENDA } \\
\text { SI }\end{array}$ \\
\hline $\begin{array}{l}\text { GINA } \\
\text { RAHAY } \\
\text { U } \\
\text { MEILAN } \\
\text { I }\end{array}$ & $\mathrm{C}$ & B & $\mathrm{C}$ & $\mathrm{C}$ & $\mathrm{Y}$ & $\mathrm{Y}$ & $\begin{array}{l}\text { SEDAN } \\
\text { G }\end{array}$ & $\begin{array}{c}\text { REKOMENDA } \\
\text { SI }\end{array}$ \\
\hline $\begin{array}{l}\text { ABDUL } \\
\text { MIMAR } \\
\text { HIDAYA } \\
\mathrm{T} \\
\end{array}$ & C & $\mathrm{C}$ & S & $\mathrm{S}$ & $\mathrm{Y}$ & $\mathrm{Y}$ & JAUH & $\begin{array}{l}\text { REKOMENDA } \\
\text { SI }\end{array}$ \\
\hline $\begin{array}{l}\text { YUSUP } \\
\text { SETIAW } \\
\text { AN }\end{array}$ & $\mathrm{S}$ & B & S & S & $\mathrm{Y}$ & $\mathrm{Y}$ & JAUH & $\begin{array}{c}\text { REKOMENDA } \\
\text { SI }\end{array}$ \\
\hline $\begin{array}{l}\text { SITI } \\
\text { WULAN }\end{array}$ & $\mathrm{C}$ & B & $\mathrm{S}$ & $\mathrm{S}$ & $\mathrm{T}$ & $\mathrm{T}$ & $\begin{array}{c}\text { SEDAN } \\
\text { G }\end{array}$ & $\begin{array}{c}\text { REKOMENDA } \\
\text { SI }\end{array}$ \\
\hline
\end{tabular}




\begin{tabular}{|c|c|c|c|c|c|c|c|c|c|c|c|c|c|c|c|c|c|}
\hline $\begin{array}{l}\text { Nama } \\
\text { Calon }\end{array}$ & \multicolumn{4}{|c|}{ Nilai Seleksi } & B & $\mathrm{O}$ & $\mathrm{J}$ & ipksms 1-6 & Nama & \multicolumn{4}{|c|}{ Nilai Seleksi } & B & $\mathrm{O}$ & $\mathrm{J}$ & ipksms 1-6 \\
\hline SARI & & & & & & & & & RIANA & $\mathrm{K}$ & $\mathrm{C}$ & $K$ & $\mathrm{~S}$ & & & & REKOMENDA \\
\hline SURYA & & & & & & & & REKOMENDA & AZIS & & & & & $\mathrm{T}$ & $\mathrm{Y}$ & DEKAT & \\
\hline $\begin{array}{l}\text { GUSTIA } \\
\text { WAN }\end{array}$ & $\mathrm{S}$ & B & $\mathrm{K}$ & $\mathrm{S}$ & Y & $\mathrm{Y}$ & $\begin{array}{l}\text { SEDAN } \\
\text { G }\end{array}$ & SI & $\begin{array}{l}\text { SRI } \\
\text { ARNA }\end{array}$ & T & . & , & S & & & & $\begin{array}{c}\text { REKOMENDA } \\
\text { SI }\end{array}$ \\
\hline $\begin{array}{l}\text { INDRI } \\
\text { INDRIA }\end{array}$ & $\mathrm{S}$ & B & $\mathrm{S}$ & $\mathrm{S}$ & & & SEDAN & $\begin{array}{c}\text { REKOMENDA } \\
\text { SI }\end{array}$ & $\begin{array}{l}\text { WINOR } \\
\text { A }\end{array}$ & S & $\mathrm{S}$ & K & $\mathrm{s}$ & $\mathrm{T}$ & $\mathrm{T}$ & DEKAT & \\
\hline NSYAH & & & & & $\mathrm{T}$ & $\mathrm{T}$ & G & & RAHMA & & & & & & & & \\
\hline $\begin{array}{l}\text { MIA } \\
\text { MARDI } \\
\text { AH }\end{array}$ & $\mathrm{C}$ & $\mathrm{C}$ & $\mathrm{K}$ & $\mathrm{S}$ & $\mathrm{T}$ & $\mathrm{T}$ & JAUH & $\begin{array}{c}\text { REKOMENDA } \\
\text { SI }\end{array}$ & $\begin{array}{l}\text { TULLA } \\
\mathrm{H} \\
\text { TEGUH }\end{array}$ & $\mathrm{S}$ & S & K & $\mathrm{K}$ & & & SEDAN & \\
\hline KUSNIA & $\mathrm{S}$ & $C$ & $S$ & $\mathrm{~K}$ & & & SEDAN & REKOMENDA & PANCA & & & & & $\mathrm{Y}$ & $\mathrm{T}$ & G & KURANG \\
\hline $\begin{array}{l}\text { RTI } \\
\text { SONI }\end{array}$ & $\mathrm{s}$ & $C$ & $\mathrm{~s}$ & $\mathrm{~K}$ & $\mathrm{~T}$ & $\mathrm{~T}$ & G & $\frac{\text { SI }}{\text { REKOMENDA }}$ & SOPIAH & $\mathrm{S}$ & $\mathrm{S}$ & K & $\mathrm{K}$ & $\mathrm{T}$ & $\mathrm{T}$ & $\begin{array}{c}\text { SEDAN } \\
\mathrm{G}\end{array}$ & $\begin{array}{c}\text { REKOMENDA } \\
\text { SI }\end{array}$ \\
\hline $\begin{array}{l}\text { MUHAM } \\
\text { AD } \\
\text { SIDIK }\end{array}$ & $\mathrm{S}$ & $\mathrm{C}$ & $\mathrm{S}$ & $S$ & $\mathrm{Y}$ & $\mathrm{Y}$ & $\begin{array}{c}\text { SEDAN } \\
\text { G }\end{array}$ & SI & $\begin{array}{l}\text { YUNI } \\
\text { MUHAR } \\
\text { ANI }\end{array}$ & $\mathrm{K}$ & $S$ & $S$ & K & $\mathrm{T}$ & $\mathrm{Y}$ & DEKAT & KURANG \\
\hline $\begin{array}{l}\text { MUNA } \\
\text { WAR }\end{array}$ & $\mathrm{C}$ & B & $\mathrm{K}$ & $\mathrm{K}$ & & & & & ASEP & $\mathrm{K}$ & $\mathrm{K}$ & $\mathrm{K}$ & $\mathrm{K}$ & $\mathrm{Y}$ & $\mathrm{Y}$ & DEKAT & KURANG \\
\hline
\end{tabular}

Ket:

$\mathrm{V}=$ Verbal, $\mathrm{K}=$ Kuantitatif, $\mathrm{P}=$ Penalaran, $\mathrm{W}=$ Wawancara

$\mathrm{B}$ : Bekerja, $\mathrm{O}=$ Organisasi, J=Jarak

$\mathrm{K}=$ Kecil, $\mathrm{S}=$ Sedang, $\mathrm{C}=$ Cukup, $\mathrm{B}=$ Besar

\section{Data Uji}

Data uji merupakan data yang akan diujikan kedalam sistem dalam hal data calon mahasiswa baru. Data yang diujikan kepada calon mahasiswa baru sama seperti data latih yaitu nilai hasil ujian tulis dan hasil wawancara. Nilai tersebut antara lain nilai seleksi yang berupa nilai Verbal, Kuantitatif, Penalaran, wawancaran, Pekerjaan, organisasi dan jarak lokasi tempat tinggal. Data uji ini akan disimpan didatabase dan ditampilkan ke layar jika dibutuhkan.

\section{Proses Seleksi Masuk Perguruan Tinggi menggunakan Naïve Bayes Classifier}

Proses seleksi masuk Perguruan tinggi di Institut Pendidikan Indonesia diawali dengan data latih pada tabel 4.1. Kemudian selanjutnya masuk sebuah data baru dalam hal ini calon mahasiswa baru. Data calon mahasiswa baru tersebut akan diolah menggunakan naïve bayes classifier berdasarkan data latih sehingga akan dihasilkan rekomendasi apakah calon mahasiswa tersebut direkomendasikan lulus atau tidak. Sebagai contoh data calon mahasiswa baru sebagai berikut:

Tabel 4.2 Data calon mahasiswa baru

\begin{tabular}{|c|c|c|c|c|c|c|c|c|}
\hline Nama & $\mathbf{V}$ & $\mathbf{K}$ & $\mathbf{P}$ & $\mathbf{W}$ & $\mathbf{B}$ & $\mathbf{O}$ & $\mathbf{J}$ & Hasil \\
\hline Anto & $\mathbf{C}$ & $\mathrm{C}$ & $\mathrm{S}$ & $\mathrm{S}$ & $\mathrm{T}$ & $\mathrm{T}$ & $5 \mathrm{~km}$ & $?$ \\
\hline
\end{tabular}

$\mathrm{V}=$ Verbal, $\mathrm{K}=$ Kuantitatif, $\mathrm{P}=$ Penalaran, $\mathrm{W}=$ Wawancara

$\mathrm{B}:$ Bekerja, $\mathrm{O}=$ Organisasi, J=Jarak

$\mathrm{K}=$ Kecil, $\mathrm{S}=$ Sedang, $\mathrm{C}=$ Cukup, $\mathrm{B}=$ Besar

Dengan menggunakan naïve bayes classifier maka proses seleksi calon mahasiswa baru adalah sebagai berikut:

a. Tahap 1 : Menghitung Class / Label Kelulusan 
$\mathrm{P}(\mathrm{Y}=$ Rekomendasi $)=42 / 65=0.646$

$\mathrm{P}(\mathrm{Y}=$ Kurang $)=23 / 65=0.353$

b. Tahap 2 : Menghitung per Kelas / label

Kelulusan

$\mathrm{P}(\mathrm{PMP}=$ Cukup $\mid \mathrm{Y}=$ Rekomendasi $)=7 / 42=$ 0.166

$\mathrm{P}(\mathrm{PMP}=$ Cukup $\mid \mathrm{Y}=$ Kurang $)=3 / 23=0.130$

$\mathrm{P}(\mathrm{IND}=$ Cukup $\mid \mathrm{Y}=$ Rekomendasi $)=19 / 42=$ 0.452

$\mathrm{P}(\mathrm{IND}=$ Cukup $\mid \mathrm{Y}=$ Kurang $)=7 / 23=0.304$

$\mathrm{P}(\mathrm{ING}=$ Sedang $\mid \mathrm{Y}=$ Rekomendasi $)=14 / 42=$ 0.333

$\mathrm{P}(\mathrm{ING}=$ Sedang $\mid \mathrm{Y}=$ Kurang $)=6 / 23=0.260$

$\mathrm{P}(\mathrm{MTK}=$ Sedang $\mid \mathrm{Y}=$ Rekomendasi $)=16 / 42=$ 0.380

$\mathrm{P}(\mathrm{MTK}=$ Sedang $\mid \mathrm{Y}=$ Kurang $)=7 / 23=0.304$

$\mathrm{P}($ Bekerja $=$ Tidak $\mid \mathrm{Y}=$ Rekomendasi $)=23 / 42$ $=0.547$

$\mathrm{P}($ Bekerja $=$ Tidak $\mid \mathrm{Y}=$ Kurang $)=13 / 23=$ 0.565

$\mathrm{P}($ Organisasi $=$ Tidak $\mid \mathrm{Y}=$ Rekomendasi $)=$ $23 / 42=0.547$

$\mathrm{P}($ Organisasi $=$ Tidak $\mid \mathrm{Y}=$ Kurang $)=18 / 23=$ 0.782

$\mathrm{P}($ Jarak $=$ Jauh $\mid \mathrm{Y}=$ Rekomendasi $)=15 / 42=$ 0.357

$\mathrm{P}($ Jarak $=$ Jauh $\mid \mathrm{Y}=$ Kurang $)=11 / 23=0.478$

c. Tahap 3 : Menentukan variable rekomendasi dan variable kurang

$\mathrm{P}(\mathrm{PMP}=$ Cukup $\mathrm{x}$ IND=Cukup $\mathrm{x}$ ING=Sedang $\mathrm{x}$ MTK=Sedang $\mathrm{x}$ Bekerja=Tidak $\mathrm{x}$ Org=Tidak $\mathrm{x}$ Jarak=jauh $\mid$ Rekomendasi )

$\mathrm{P} \mid$ Rekomendasi $=0.166 \times 0.452 \times 0.333 \times$ $0.380 \times 0.547 \times 0.547 \times 0.357=\mathbf{0 . 0 0 1 3 0}$

$\mathrm{P} \mid$ Kurang $=0.130 \times 0.304 \times 0.260 \times 0.304 \times$ $0.565 \times 0.782 \times 0.478=0.00067$

Karena P | Rekomendasi lebih besar dari P | kurang maka hasil dari data calon mahasiswa baru tersebut direkomendasikan untuk diterima.

\section{Perancangan perangkat lunak model Waterfall}

Desain penelitian menggunakan model sekuensial linear atau sering disebut dengan model air terjun (waterfall). Desain penelitian dapat dilihat pada gambar berikut:

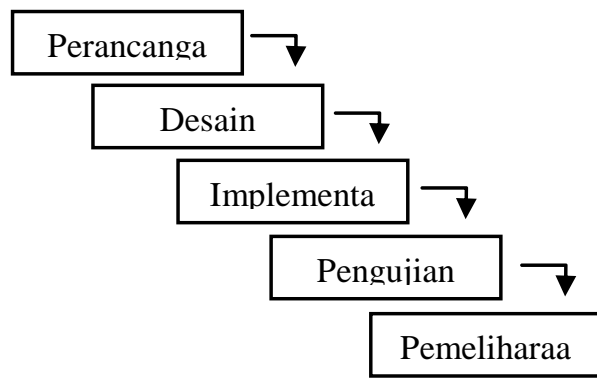

\section{Gambar 4.2 Model Waterfall}

Desain penelitian meliputi aktivitas-aktivitas berikut: Pemodelan sistem informasi harus dilakukan terlebih dahulu sebelum mulai melakukan implementasi program atau pengkodean program. Pemodelan sistem informasi ini bertujuan untuk menemukan batasan-batasan masalah pada penerapan sistem.

\section{Analisis}

Tahan ini merupakan tahap awal dalam pengembangan sebuah perangkat lunak, tahapan ini digunakan untuk mengetahui informasi, model, dan spesifikasi dari sistem yang dibutuhkan, baik kebutuhan fungsional maupun kebutuhan non fungsional.

Kebutuhan funsional merupakan kebutuhan utama yang berkaitan langsung dengan pelayanan sistem pengambilan keputusan yang meliputi dibagi menjadi beberapa modul seperti yang tercantum dalam tabel di bawah ini:

Tabel 4.3 Kebutuhan Fungsionl

\begin{tabular}{|l|l|}
\hline No & \multicolumn{1}{|c|}{ Deskripsi Kebutuhan Fungsional } \\
\hline 1 & $\begin{array}{l}\text { User login untuk pengelola sistem } \\
\text { pengambilan keputusan menggunakan Naïve } \\
\text { Bayes Classifier. }\end{array}$ \\
\hline 2 & $\begin{array}{l}\text { Pengelolaan data latih secara manual pada } \\
\text { sistem pengambilan keputusan berupa } \\
\text { tambah data latih, edit data latih dan delete } \\
\text { data latih. }\end{array}$ \\
\hline 3 & $\begin{array}{l}\text { Pengelolaan data latih menggunakan import } \\
\text { excel. }\end{array}$ \\
\hline 4 & $\begin{array}{l}\text { Pencarian data latih yang telah di masukan } \\
\text { kedalam database }\end{array}$ \\
\hline 5 & $\begin{array}{l}\text { Pengelolaan data testing berupa input data, } \\
\text { edit data dan delete data }\end{array}$ \\
\hline 6 & $\begin{array}{l}\text { Pencarian data testing yang telah dimasukan } \\
\text { kedalam database }\end{array}$ \\
\hline 7 & $\begin{array}{l}\text { Hasil rekomendasi dari pengolahan } \\
\text { menggunakan Naïve Bayes Classifier. }\end{array}$ \\
\hline
\end{tabular}


Tabel 4.4 Kebutuhan non fungsional

\begin{tabular}{|l|l|}
\hline No & \multicolumn{1}{|l|}{ Deskripsi Kebutuhan Non-Fungsional } \\
\hline 1 & $\begin{array}{l}\text { Username dan password di enkripsi dengan } \\
\text { md5. }\end{array}$ \\
\hline 2 & $\begin{array}{l}\text { Validasi format username tanpa spasi dan } \\
\text { maximal 10 karakter. }\end{array}$ \\
\hline 3 & $\begin{array}{l}\text { Authentication dan Otorization user } \\
\text { berdasarkan username, password. }\end{array}$ \\
\hline 4 & Menentukan waktu idle pengaksesan. \\
\hline 5 & Tersedia 24 jam sehari, 7 hari seminggu \\
\hline 6 & $\begin{array}{l}\text { Tidak pernah gagal dalam menampilkan, } \\
\text { menginput atau mengubah informasi. }\end{array}$ \\
\hline 7 & $\begin{array}{l}\text { Kemudahan pemakaian pada sistem yang } \\
\text { sesuai. }\end{array}$ \\
\hline 8 & Interface menggunakan Bahasa Indonesia. \\
\hline 9 & $\begin{array}{l}\text { Selalu muncul pesan kesalahan jika terjadi } \\
\text { error. }\end{array}$ \\
\hline
\end{tabular}

\section{Desain Sistem}

Tahapan kedua dari model waterfall adalah desain dimana pada tahapan ini bertujuan membuat desain dari hasil analisis yang dilakukan pada tahapan pertama. Informasi, model dan spesifikasi yang diubah menjadi sebuah desain sistem yang nantinya akan dikodekan.

Data Flow Diagram atau DFD adalah salah satu tools penting yang digunakan oleh analis sistem.Penggunaan DFD dipopulerkan oleh DeMarco (1978) dan Gane \& Sarson (1979) melalui metodologi analisis sistem terstruktur (structured systems analysis methodologies). Mereka menganjurkan agar DFD menjadi alat pertama yang digunakan "analis sistem" untuk membuat sebuah model sistem yang menunjukkan keterkaitan setiap komponen-komponen sistemnya. Komponen sistem tersebut adalah prosesproses dalam sistem, data yang digunakan oleh proses-proses tersebut, eksternal entitas yang berinteraksi dengan sistem dan aliran data/informasi di dalam sistem. Dibawah ini gambar dari DFD untuk sistem pengambil keputusan

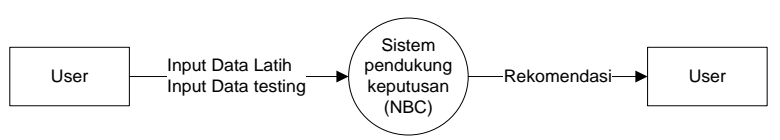

Gambar 4.3 Kontek diagram

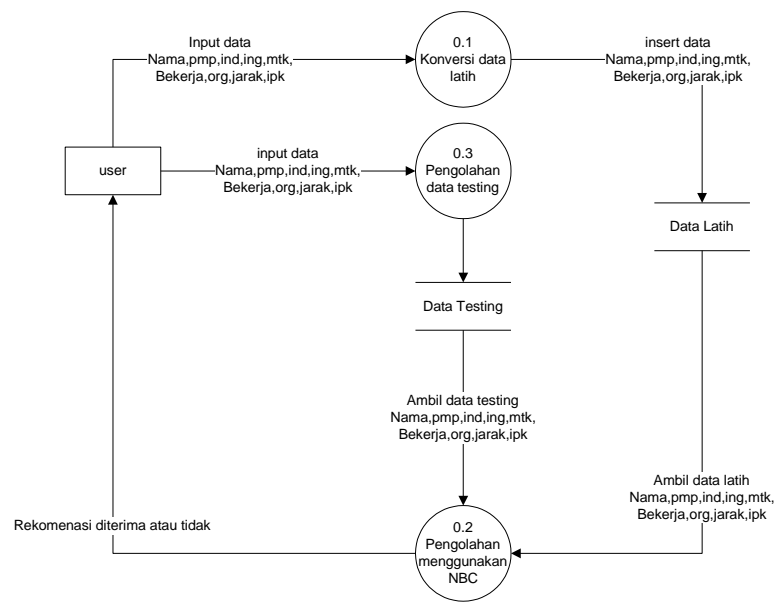

Gambr 4.4 DFD Level 1

Gambar DFD diatas merupakan gambaran dari alur data yang ada pada sistem pengembilan keputusan NBC. Dibawah ini merupakan penjelasan dari lebih lengkap dari alur datanya.

1) Peran dari entitas user adalah untuk memberikan masukan berupa data latih maupun data testing, selain itu entitas ini juga berperan menerima informasi dari sistem informasi berupa rekomendasi siswa mana yang akan direkomendiasikan atau tidak.

2) Peran dari proses konversi data latih adalah menerima masukan dari entitas user berupa input, edit dan delete data. Selanjutnya masukan yang dilakukan akan diolah oleh proses ini dengan cara mengkonversi nilai menjadi sekala penilaian.

3) Peran dari proses konversi data latih adalah menerima masukan dari entitas user berupa input, edit dan delete data. Selanjutnya masukan yang dilakukan akan disimpan kedalam data testing.

4) Peran dari proses pengolahan menggunakan NBC adalah membandingkan data latih dan data testing menjadi sebuah rekomendasi menggunakan algoritma Naïve Bayes Classifier.

5) Data latih digunakan untuk menyimpan datadata latih yang nantinya akan digunakan oleh proses pengolahan menggunakan NBC.

6) Data testing digunaan untuk menyimpan datadata testing yang nantinya akan digunakna oleh proses pengolahan menggunakan NBC.

Selain membuat desain sistem untuk alur data, dalam desain perangkat lunak juga ada yang desain untuk menggambarkan basis data yang digunakan dalam perangkat lunak. Basis data merupakan tempat 
penyimpanan data-data, dalam penelitian ini basis data dibuat untuk menumpan data latih, data user dan data testing. Berikut ini basis data untuk sistem pengambilan keputusan NBC.

\begin{tabular}{|l|l|}
\hline \multicolumn{2}{|c|}{ User } \\
\hline PK & $\underline{\text { id }}$ \\
\hline & $\begin{array}{l}\text { nama } \\
\text { username } \\
\text { password } \\
\text { status }\end{array}$ \\
\hline
\end{tabular}

\begin{tabular}{|l|l|}
\hline \multicolumn{2}{|c|}{ Data Latih } \\
\hline PK & id \\
\hline & nama \\
& pmp \\
ind \\
ing \\
& mtk \\
& bekerja \\
& org \\
& jarak \\
& ipk \\
\hline
\end{tabular}

\begin{tabular}{|l|l|}
\hline \multicolumn{2}{|c|}{ Data Testing } \\
\hline PK & $\underline{\text { id }}$ \\
\hline & no_reg \\
& nama \\
& pmp \\
& indo \\
& ing \\
& mtk \\
& bekerja \\
& org \\
& jarak \\
ipk
\end{tabular}

Gambar 4.5 Rancangan basis data

1) Tabel user digunakan untuk menyimpan data user, seperti nama, username, password dan status.

2) Tabel data latih digunakan untuk menyimpan data-data latih yang nantinya akan digunakan untuk pengolahan. Data yang dimasukan kedalam data latih ini antara lain: nama, nilai pmp, nilai ind, nilai ing, nilai mtk, status bekerja, status organisasi, jarak rumah ke kampus, ipk.

3) Tabel data testing digunakan untuk menyimpan data-data testing yang nantinya akan digunakan untuk pengolahan. Data yang dimasukan kedalam data latih ini antara lain: nama, nilai pmp, nilai ind, nilai ing, nilai $\mathrm{mtk}$, status bekerja, status organisasi, jarak rumah ke kampus, ipk.

\section{Implementasi / Koding}

Tahap selanjutnya dari model Waterfall dalam pengembangan sistem pengambilan keputusan adalah tahap impementasi. Tahapan ini ada tahap pengembangan dengan melakukan pengkodean. Hasil dari pengkodean menghasilkan perangkat lunak. Pada penelitian ini perangkat lunak pada sistem pengambilan keputsan NBC antara lain:

Gambar 4.6 dibawah ini merupakan tampilan login untuk pengguna. Halaman login utama merupakan tampilan awal ketika pengguna akan masuk ke sistem. Pengguna akan diminta memasukan username dan password ketika akan masuk ke sistem tersebut.

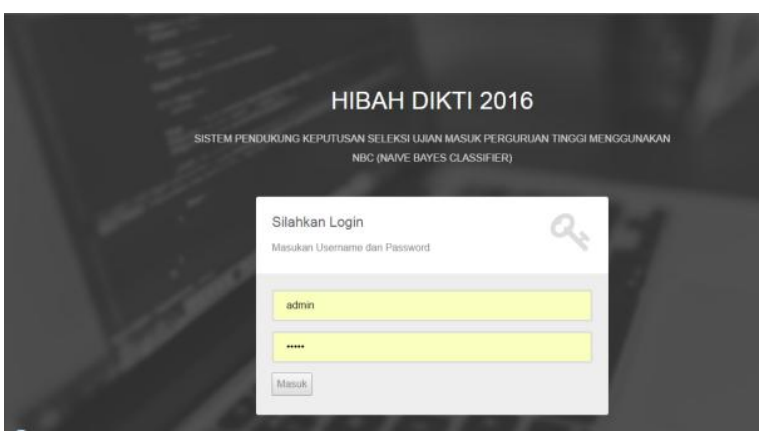

Gambar 4.6 Halaman login

Selanjutnya Gambar 4.7 merupakan gambaran dashboard ketika pengguna berhasil melakukan login. Pada halaman dashboard ini pengguna dapat memilih menu yang telah disediakan diantaranya menu dashboard, data latih dan data testing.

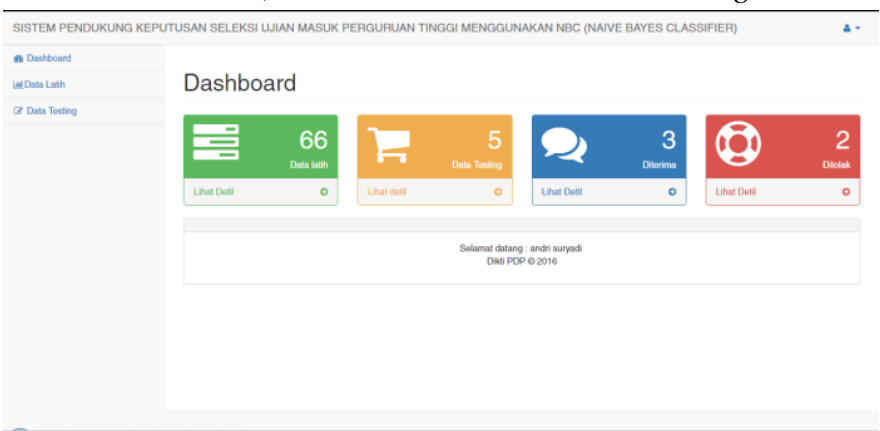

Gambar 4.7 Halaman Dashboard

Kemudian pada menu data latih akan ditampilkan semua data latih dan juga disediakan tombol tambah data seperti pada gambar 3.8.

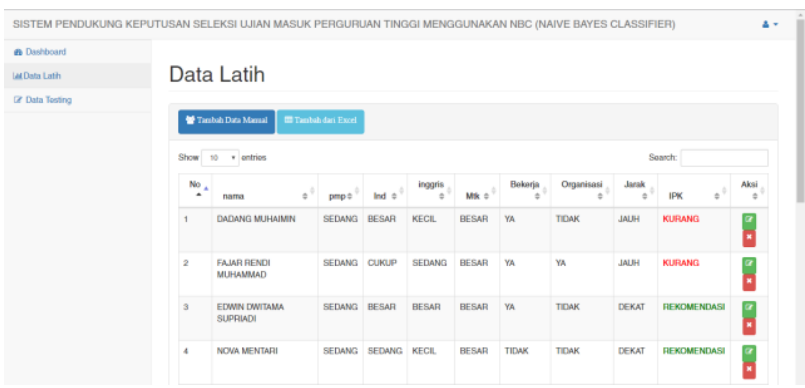

Gambar 4.8 Halaman data latih

Pada gambar 3.9 merupakan tambah data latih jika pengguna akan menambahkan data latih.

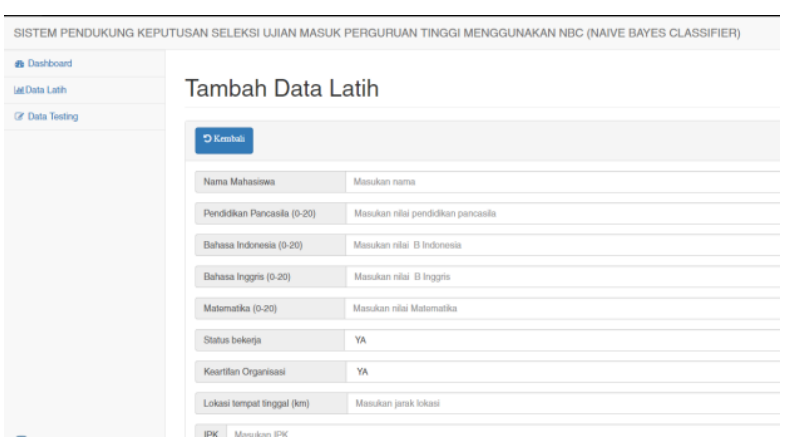

Gambar 4.9 Halaman Tambah data latih 
Selanjutnya menu data testing dapat dilihat pada gambar 4.10. Menu data testing ini pengguna akan melihat hasil dari pengolahan data mahasiswa disertai hasil rekomendasi atau kurang direkomendasikan. Setelah itu pengguna juga dapat menambah data testing baru seperti dilihat pada gambar 4.11.

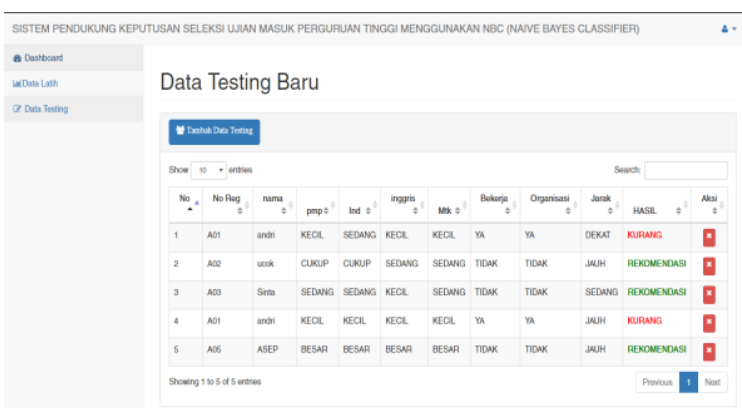

Gambar 4.10 Pengelolaan Data Testing

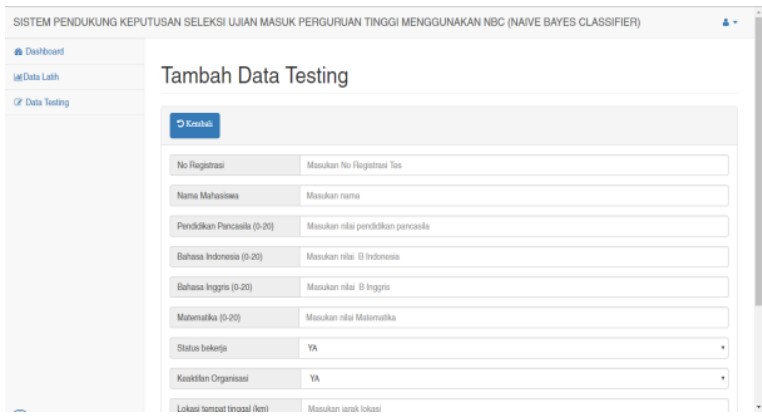

Gambar 4.11 halaman Tambah Data Testing

\section{Pengujian}

Tahapan terakhir dalam model waterfall adalah tahapan pengujian, dimana pada tahapan ini software yang telah dibuat diuji apakah sudah sesuai dengan kubutuhan atau belum. Dalam pengujian software ini dilakukan dengan pengujian Blackbox. Dibawah ini adalah sekenario yang dilakukan dalam pengujian menggunakan Blackbox:

Tabel 4.5 Pengujian Sistem

\begin{tabular}{|c|c|c|}
\hline Keterangan & $\begin{array}{l}\text { Scenario } \\
\text { pengujian }\end{array}$ & $\begin{array}{c}\text { Hasil } \\
\text { Pengujian }\end{array}$ \\
\hline 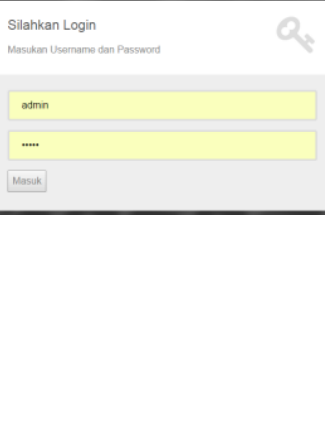 & $\begin{array}{lr}\text { User } & \text { akan } \\
\text { memasukan } & \\
\text { username } & \text { dan } \\
\text { password } & \text { pada } \\
\text { halaman } & \text { yang } \\
\text { tersedia. } & \text { Apabila } \\
\text { username } & \text { dan } \\
\text { password } & \text { salah } \\
\text { maka akan } & \text { keluar } \\
\text { peringantan } \\
\text { username } \\
\text { password salah. }\end{array}$ & Berhasil \\
\hline
\end{tabular}

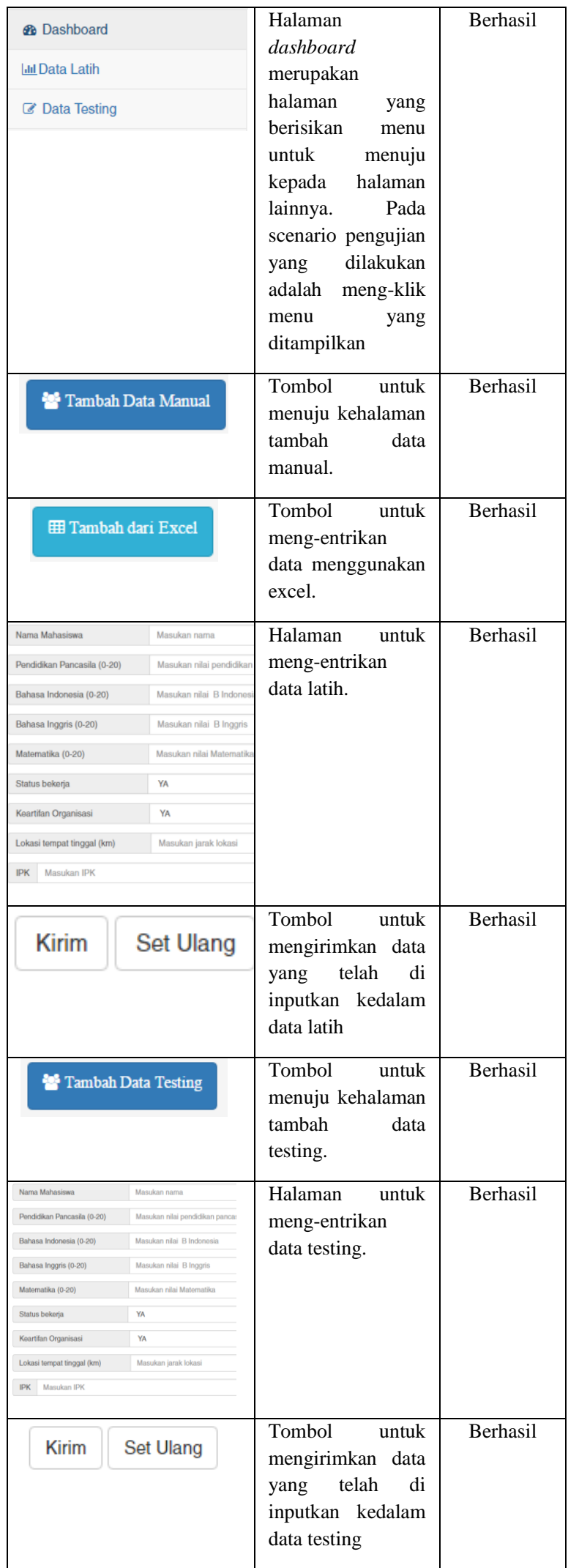




\begin{tabular}{|l|l|l|l|}
\hline HASIL & & $\begin{array}{l}\text { Tampilan tabel } \\
\text { hasil pengolahan } \\
\text { menggunakan } \\
\text { NBC yang } \\
\text { menghasilkan } \\
\text { rekomendasi untuk } \\
\text { pengambilan } \\
\text { keputusan. }\end{array}$ & \\
\hline KURANG & Berhasil \\
\hline REKOMENDASI & & \\
\hline REKOMENDASI & & $\begin{array}{l}\text { Tombol untuk } \\
\text { menghapus data } \\
\text { latih maupun data } \\
\text { testing }\end{array}$ & Berhasil \\
\hline KURANG & & \\
\hline & & \\
\hline
\end{tabular}

\section{KESIMPULAN DAN SARAN}

\section{Kesimpulan}

Dari penelitian yang telah dilakukan terdapat beberapakesimpulan sebagai berikut:

1) Sistem pendukung keputusan seleksi ujian masuk perguruan tinggi menggunakan naïve bayes classifier merupakan sistem yang dapat membantu dalam menyeleksi calon mahasiswa baru.

2) Sistem pendukung keputusan seleksi ujian masuk perguruan tinggi menggunakan naïve bayes classifier dapat meningkatkan kualitas input terhadap perguruan tinggi.

\section{Saran}

Saran dari peneliti untuk pembaca adalah sebagai berikut:

1) Keakuratan metode naïve bayes classifier tergantung banyaknya data latih oleh karena itu perlu dicoba dengan

2) data latih yang lebih banyak lagi.Perlu adanya pengembangan terhadap sistem misalnya dengan membuat sistem berbasis mobile.

\section{PUSTAKA}

A. G. Mabrur and R. Lubis.2012. "Penerapan Data Mining untuk Memprediksi Kriteria Nasabah Kredit," Jurnal Komputer dan Informatika (KOMPUTA), vol. 1, pp. 53-57

Fahrurozi Achmad. 2014. Klasifikasi Kayu Dengan Menggunakan Naive Bayes-Classifier. KNM XVII ITS Surabaya
Giovani, Ronny Ardi.2011. Sistem Pendukung Keputusan Prediksi Kecepatan Studi Mahasiswa Menggunakan Metode ID3. Universitas Atmajaya Yogyakarta.

Mustaqbal1.M. Sidi, Firdaus.Roeri Fajri , Rahmadi.Hendra. 2015 . Pengujian Aplikasi Menggunakan Black Box Testing Boundary Value Analysis.Jurusan Teknik Informatika, Fakultas Teknik, Universitas Widyatama. Jurnal Ilmiah Teknologi Terapan ISSN : 2407 - 3911.

Nugroho Yuda Septian. Data Mining Menggunakan Algoritma Naive Bayes Untuk Klasifikasi Kelulusan Mahasiswa Universitas Dian Nuswantoro. Jurusan Sistem Informasi, Fakultas Ilmu Komputer, Universitas Dian Nuswantoro

Pressman, Roger S. 2002.’'Rekayasa Perangkat Lunak (Pendekatan Praktis)." Yogyakarta : Andi.

Rodiyansyah, Sandi Fajar dan Winarko Edi.2012. Klasifikasi Posting Twitter Kemacetan Lalu Lintas Kota Bandung Menggunakan Naive Bayesian Classification. FPMIPA UGM Yogayakarta

S Andri, E Harapap.2017. Pemeringkatan Pegawai Berprestasi Menggunakan Metode AHP (Analytic Hierarchy Process) di PT. XYZ. Jurnal Teori dan Terapan Matematikan Vol.16 No.2 2017

Shalahuddin, M dan Rosa AS. 2014. Rekayasa Perangkat Lunak terstruktur dn berbasis Objek. INFORMATIKA

Sommerville.Ian.2004.Software Enggineering:7th Edition. McGraw-Hill

Suryadi.Andri, Nurdiana, Dian.2015. Sistem Pengambilan Keputusan Untuk Pemilihan Teknisi Lab Dengan Multi Kriteria Menggunakan Metode Ahp (Analytic Hierarchy Process). Jurnal Mosharafa Vol.4 No.1 Januari 2015

Suryadi.Andri, Nurdiana Dian.2016. Sistem Pendukung Keputusan Seleksi Ujian Masuk Perguruan Tinggi Menggunakan Nbc (Naïve Bayes Classifier). Jurnal Kinetik Vol.1 No.3 2016 Hal 173-182

Suryadi,. Andri.2015. PERANCANGAN APLIKASI TES BERBASIS KOMPUTER (CBT) MENGGUNAKAN PENDEKATAN TERSTRUKTUR UNTUK PENERIMAAN MAHASISWA BARU DI PERGURUAN TINGGI. Petik Vol.1 No.1 2015 Hal. 68-81.

Wahyunningrum.Tenia, Januarita.Dwi.2015. Implementasi dan Pengujian Web E-commerce untuk Produk Unggulan Desa. Jurnal Politeknik Caltex Riau Vol.1 no.1 hal 57-66. 